\title{
Story-Reading as a Teaching Method for Young Children: Teacher's Challenges
}

\author{
Ghitha Loka Yuniar, Euis Kurniati \\ Universitas Pendidikan Indonesia, Setiabudhi, Bandung, Indonesia \\ Corresponding e-mail: lokamuonline@gmail.com
}

\begin{abstract}
Reading as one of language skill plays an important role these days. Young children who enjoy reading do it more often and they tend to become skilled at it. Poor readers, by contrast, often display low motivation to read. In fact, many Indonesian children still have low motivation in reading. They prefer watching TV rather than reading books. Not only at home, reading motivation may be able to be stimulated from school. The teacher at school also has the same role to ,sink" children deeply into literacy and make them usual with it. One of methods used to let children get involved to the literacy is storyreading session. Implementing story-reading in the classroom with children is not without any challenges faced. So, the question raised in this study is about teacher's challenges faced before, during, and after story-reading in the classroom. Thus, this study was aimed at describing challenges faced by teachers in initiating reading interest on young children. This present study applied qualitative descriptive in order to get depth understanding. The data were obtained from various resources such as observations, interviews, teacher's journals, and documentations. The respondent of this study is a teacher from a kindergarten, Bandung, West Java. The teacher's challenges found in this study were from the lack of references of good and suitable educated storybooks, either in terms of the plot/content, font size, or the design. Another challenge was found in the steps (before-during-after) technically of story-reading. Thus, the result shows that the teacher did familiarize herself with the ideal steps of story-reading so the challenges faced during story-reading activity could be handled well. Then it is also indicates that children had high motivation and enthusiasm in story-reading activities and they became familiar by listening and reading from the storybooks.
\end{abstract}

Keywords: $\quad$ story-reading, reading storybooks, teacher's challenges

\section{INTRODUCTION}

Reading is an important language skill and a highly complicated act that everyone must learn. Reading is not a single skill but a combination of many skills and processes in which the readers interact with printed words and texts for content and pleasure. Some kindergartens in Indonesia are used to motivating children with reading using "Bacalah" book which contains spellings or words without meaning. Whereas the basic goals of reading for children are to enable them to gain an understanding of the world and themselves, to develop appreciation and interests, and to find solutions to their personal and group problems (Calkins, 2001).

Thus, one of the methods that can help children to have an ,affair' with literacy is by using the story- reading method. It is in line with $\operatorname{Rog}(2001)$ who states that reading stories aloud is meant to develop children's "concepts about print, story structure, and other elements of text" and "provides the child with a wealth of information about the processes and functions of written language"; it is like a TV or radio ad for literature. Story-reading time encourages children to grow as readers and broadens the types of literature they choose to read (Harste et al., 1988). The single most important activity for building required knowledge for eventual success in reading is by reading it aloud to children.

Children always love story-reading or reading aloud as a language activity because it can be very fun to learn if it is delivered by the right person (in this case, the teacher) (Wright, 2009). In fact, many kindergartens in Indonesia rarely implement story- 
time activity in the classroom. Thus, it affected to the teachers' ability in telling stories. The impacts may show rigidity in the inability to express and improve the story, or to explore the great part of the story. The bad impacts mentioned happen because they never challenge themselves to tell the story using the books.

This study portrayed the teacheres challenges faced in story-reading as a teaching method to young children. The challenges were found in every step of story-reading session; before, during, and after story-reading session. Such as the lack of references of good and suitable educated storybooks, either in terms of the plot/content, font size, or the design; and setting arrangement in the classroom during story-reading.

It is recommended that story-reading is used as a teaching routine in every class as a strategy, allowing children to become more familiar with literacy. Considering the importance of storyreading, the teaching model based on Budaya, Karakter Bangsa dan Bermain (BKBB) or Teaching Model based on Learning Culture, National Values, and Playing comes up with the story-reading session inside everyday classroom activity as a solution for all kindergartens.

\section{LITERATURE REVIEW}

Story-Reading (SR), or reading aloud, to children is a reading model since the teacher is demonstrating how to read to children and providing with high supports (Fellowes and Oakley, 2014). Children concentrate on enjoying and comprehending the story without a burden of trying to identify words. This type of reading does not directly drill them to read but they are unconsciously invited to ,a literacy-enriched environment ${ }^{\mathrm{ee}}$ by seeing the prints of the book cover and illustrations. It is supported by Machado (1980) who states that interaction, such as seeing, touching, and interacting with the books read is needed to be built in early childhood education quality program in order to make 'storytime' fun and meaningful.

There are a lot of teaching models that support children to love reading activity. Here, one of teaching model, named BKBB, offers kindergarten level to put play-based and culture-based in a curriculum. One of activities arrangement of BKBB model is story-reading session. It is in line with Leuenberger (2003) who believes that Story-reading or reading aloud is the foundation of a well-balanced literacy curriculum.
Storytime through Story-Reading (SR) has several steps as before, during, and after storyreading that must be done practically by the teacher. However, these steps formulated by Machado (1980), Essa, (2003), Brewster \& Ellis (2003), Wright (2009), and Harmer (2003), that are explained below, can also be challenges faced by the teacher in the classroom activities.

Before story-reading, the teacher needs to consider some criteria of picture books and the age level of the children. It is aimed at delivering a proper teaching-learning process to children in storytelling session (1st Step). The teacher reads the storybook to comprehend the flow and characters of the story (2nd Step). Moreover, the teacher also arranges the seating arrangement to provide the appropriate physical environment. Choosing the best seat arrangement depends on the activity happening, if the activity needs big area to do some movements, the ,circles' seat arrangements can be a choice; or if the activity needs more serious condition, such as having a test, the ,orderly rows' seat arrangement can be a choice to see all students more clearly. In this case, indirectly Harmer (2003) also suggests making the seating arrangement in classroom suitable for the activity have been planned (3rd Step).

During story-reading, the teacher should deliver motivational introductory statements (4th Step). The storybook is held to both your right or left side and keep the book at children ${ }^{\text {ec }}$ eye level (5th Step). In the beginning of reading process, the teacher is supposed to try to deliver the story fantastically by using proper mimic, gestures, and voice exchanged (6th Step).

After story-reading, the storybook is reviewed through a few of question-answer discussions. The questions can clear up ideas, encourage the use of vocabularies and pinpoint parts that are especially enjoyed. Or, you may ask children to guess what the end of the story like (7th Step).

Those are relevant to Kim's (1999) statement that storytelling becomes known as a key cognitive skill in process of intellectual development because the used of the story in the language classroom gives a lot of learning experiences to children naturally from the linguistics features, vocabularies, and comprehension as well.

It is important to note that story reading can sometimes incorporate elements such as movement and choral participation, thus these elements can enhance the quality and value of the story experience. It is also supported by Morrow's (1996:56) result of his research which shows that 
many experimental studies found that children in the treatment groups produce higher scores in the areas of vocabulary, story comprehension, and decoding rather than the children in the groups who are not read to. Thus, story-reading clearly is not just for fun, it also helps children learn to be better users of language, helps children learn to search for meaning, and has an impact on children "s overall academic performances.

\section{METHODOLOGY}

\subsection{Research Design}

Qualitative method was employed to answer the statement problems of this study. This study was aimed by analysing and revealing the phenomenon during teaching learning using story-reading. Thus, the writers chose specifically qualitative descriptive, as a research design, was utilized to explain information on how the activities carried out during preparation, teaching-learning process, and reflection session.

\subsection{Research Site}

The study was undertaken at a kindergarten at Bandung, West Java. The first reason for choosing this level is that teaching in kindergarten level has been wrestled by the writers for years so it made them easier to do the research in the same level. Another reason for choosing this school was responsibility because the writers were researcher and research assistant of BKBB teaching model in Bandung. Moreover, to make the observation conducted effectively, some classes of some Kindergartens for six meetings were taken to be observed. They were pre-schoolers whose ages range between 5 and 6 years old. One important thing, in this study, was the presence of teachers because they had control to create seven steps that must be done by the teacher in story-reading practically.

\subsection{Data Collection}

To collect the data, the writer relied on qualitative method to find out the teacher's challenges in implementing story-reading to motivate young children in their first reading step. Classroom observation, observation journal, interview, and documentary data were being the main sources of data collection and each of which is described below:

\subsubsection{Observation Journal}

The use of observation journal helps the writers to observe what phenomenon happened during class activities, especially in story-reading session. The journal itself is indicated as one of several approaches to narrative inquiry method. Narrative inquiry was used in this research as the reflexive process of moving from field (with starting points in telling or living of stories) to field texts (data).

\subsubsection{Interview}

Interview can provide important insight into respondent's experiences, beliefs, perceptions, and motivations. Respondent was interviewed about the challenges faced in story-reading with children, selecting Indonesia picture books, and beforeduring-after activities in implementing story-reading in the classroom.

\subsubsection{Documentary Data}

In this study, some photos were collected as documentary data. During the activities, the teacher of a kindergarten in Bandung took pictures on everything that was going on the story-reading session.

\subsection{Data Analysis}

Data analyses and interpretation were based on data mainly from observation that consist of observation journals; interview; and documentary data. Thus, all data was transcribed and subsequently categorized and interpreted in a strong body of information. In this case, the categorization and interpretation are described by the frameworks below 


\section{Categorization}

\section{Obscrvation Journal}

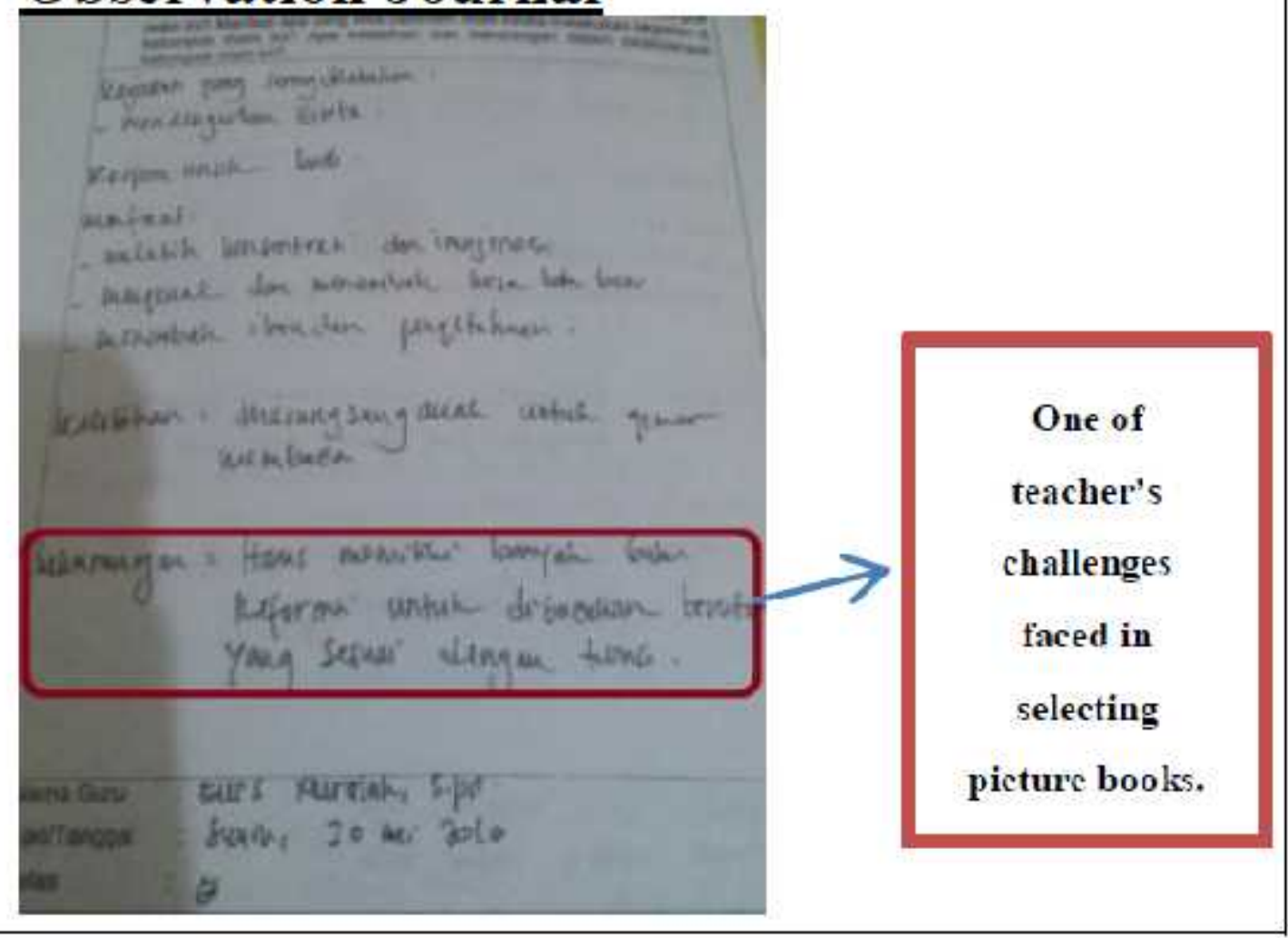

Figure 1. Example of Forming Categories from the Excerpt of Observation Journal

Table 1. Example of Framework of Story-Reading Implementation

\section{Interpretation}

\begin{tabular}{|c|c|}
\hline General l'rocedures for Story-Reading & Steps \\
\hline $\begin{array}{l}\text { Consider some criteria of picture books and the age level } \\
\text { of the childien irself }\end{array}$ & \multirow[t]{3}{*}{ Before } \\
\hline $\begin{array}{l}\text { Reat the slinglowe itself is conuprehend the flows and } \\
\text { characters of the story }\end{array}$ & \\
\hline 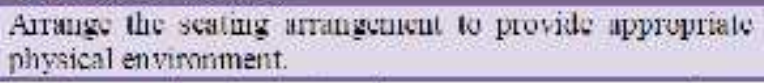 & \\
\hline $\begin{array}{l}\text { Deliver motivational introductory statements, such as } \\
\text { "1 here is a mouse in this book which is making a birthday } \\
\text { cake for her closed-fricads". }\end{array}$ & \multirow{3}{*}{ During } \\
\hline $\begin{array}{l}\text { Hold the book to cither your right or left side and koop the } \\
\text { loosk at chloldren's sye level. }\end{array}$ & \\
\hline 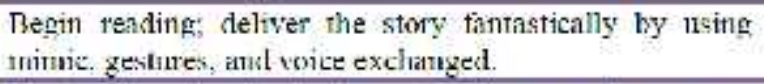 & \\
\hline $\begin{array}{l}\text { Keview the storybook through a few question-answer } \\
\text { discussions. }\end{array}$ & After \\
\hline 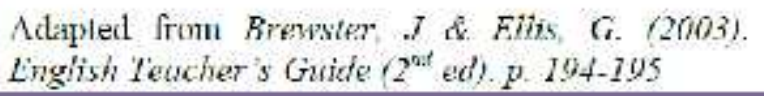 & $a r y$ \\
\hline
\end{tabular}




\section{FINDINGS AND DISCUSSIONS}

\subsection{Findings}

This section is focused on the activities performed during story-reading by using picture books which took six meetings. As stated by Machado (1980), story-reading activities were ideally divided into seven steps; (1) selection of picture books, (2) comprehension towards the story, (3) seating arrangement, (4) delivering motivational introductory, (5) the way teacher holds the book, (6) the way teacher tells the story, and (7) review session. All seven steps are classified into 3 stages, as suggested by Wright (2009), in story-reading activities, as follows:

Table 2. Summary Table during Story-Reading Activities

\begin{tabular}{ccc}
\hline \multicolumn{3}{c}{ Story-Reading Activities } \\
(Preparation) & $\begin{array}{c}\text { During } \\
\text { (Storytelling } \\
\text { time) }\end{array}$ & $\begin{array}{c}\text { After } \\
\text { (Reviewing) }\end{array}$ \\
\hline $\begin{array}{c}\text { Selection of } \\
\text { picture books; } \\
\text { comprehension } \\
\text { towards the story; } \\
\text { seating } \\
\text { arrangement. }\end{array}$ & $\begin{array}{c}\text { Delivering } \\
\text { motivational } \\
\text { introductory; the } \\
\text { way teacher holds } \\
\text { the book; the way } \\
\text { teacher tells the } \\
\text { story. }\end{array}$ & $\begin{array}{c}\text { Review session } \\
\text { through a few } \\
\text { question-answer } \\
\text { discussions. }\end{array}$ \\
\hline
\end{tabular}

Not all steps of story-reading activities are applied by the teacher. In preparation, the teacher was very selective in looking for the proper picture books, and choosing them for younger children level was the most challenging task. It was relevant to the teacher's interview that she wanted to show the picture books which are related to today's topic or theme but unfortunately, the resource of the Indonesian picture book was hard to find. The picture books sold in bookstores are mostly English book. So far, she got some Indonesia picture books from Gramedia bookstore. She chose picture books which its font and size were readable for teacher and see able for children.

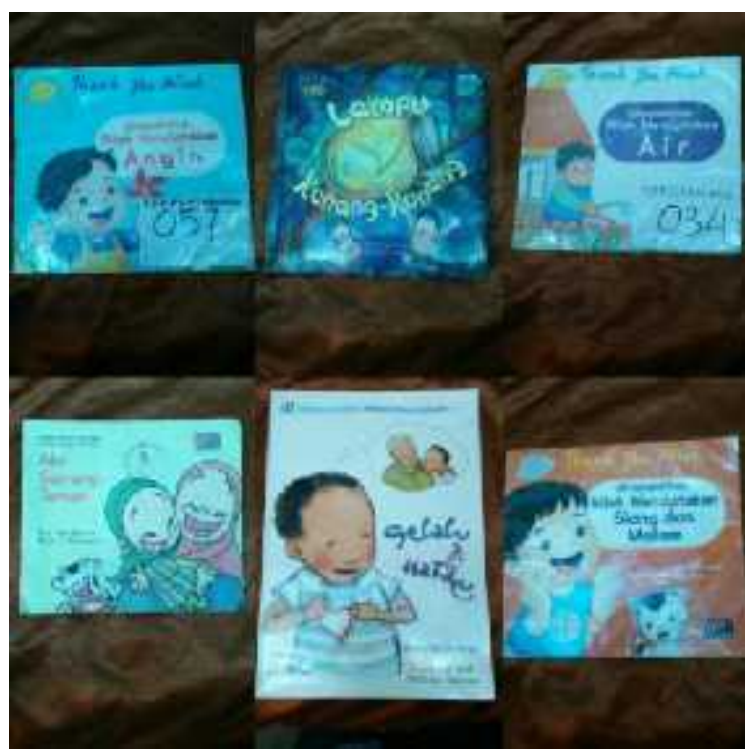

Figure 2. The Picture Books Used in Story-Reading Session

Besides, not only the selection of picture books must be appropriate but also the teacher had to set a good seating arrangement. It was important because children could see the picture books clearly and get involved in the storytelling activity. Thus, the seating arrangement was an essential preparation for the lesson plan. In contrast, the teacher did not consider the seating arrangement as an important list of the lesson plan. However, when she showed a picture book to children, they were still excited as pictured below. Some children showed curiosity with the book, thus unconsciously they wanted to stand up and question a lot of things related to the story.

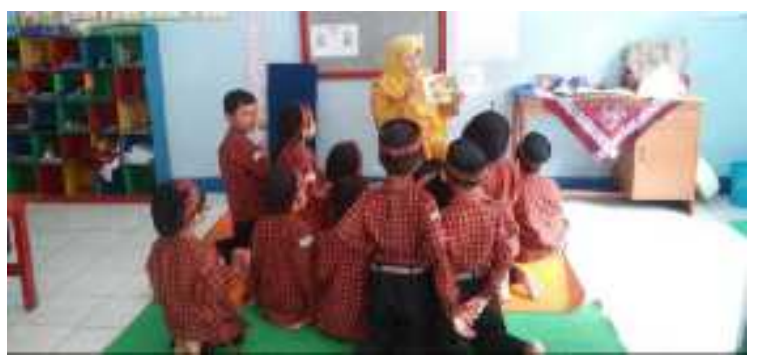

Figure 3. Teacher's Seat Arrangement in the Classroom

During the story-reading activity, the teacher, as the storyteller, is demanded to show the role off (Brewster \& Ellis, 2003). In fourth meeting, the teacher was challenged to act out and make different voices of 9 animals. Before the story session was started, she practised sounding like lion, monkey, 
elephant, goat, mouse, cat, dog, bird, and alligator. Even though it was hard to make significant differentiation for 9 characters of animal, but at least the teacher had tried to prove the requirements to become a good storyteller.

Besides, the teacher also faced some children who did not give attention.

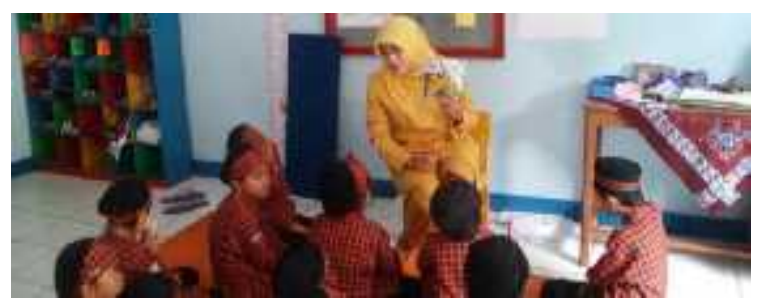

Figure 4. Unpaid Attentions of Children

When the children get bored, they usually like doing physical activity because they have belonged to the active learners (Piaget, 1963 as cited in Pinter, 2006). In the 5th and 6th meeting, the use of storyreading activity in the classroom was very usual for children. In these meetings, the teacher was challenged to handle children in video session after storytelling. Every single child in the classroom wanted to sit closer to the display and obviously it took time quite long because the teacher needed more time to let them back to their own seat.

Last activity, the teacher was always challenged to provide some question and answer session (Q\&A) to review the plot, vocabularies given, and/or discussing the characters raised from the story. Sometimes, she provided some paper to let children draw or colour their favourite character(s) or object(s) which was integrated by the today's topic. In a certain time, the researchers found that the children seemed confused to answer the teacher's questions. The confusion of children was shown by scratching head, or just being silent, or sometimes showing their silly faces. They might not understand what the questions were about or they were just shy to answer.

\subsection{Discussions}

In this case, BKBB teaching model was no longer applied in this kindergarten as a part of its curriculum. BKBB has a classroom activities arrangement which is repeated in every meeting. A focused part of classroom activities in this study is story-reading activity.

The teacher, therefore, also faced some challenges in teaching young children through story- reading. Considering children's unique characteristics (Pinter, 2006; Piaget, 1963, Mooney, 2000; Suyanto, 2008), the teacher obviously faced different wants, needs, and personalities of children. The challenges faced are generally described in the next paragraph.

The story-reading here used picture books. And the prior challenge was finding the samples of picture books. Sometimes, the books used were not proper with the themes. In contrast, the selection of picture books must be integrated to the level of children and to the ideal criteria of picture books for children. It is in line with Machado (1980) that the meaningful context in teaching vocabulary process will not achieve the goal if the teacher shows and tells the storybooks to an inappropriate level. Ideally, the picture books selected should contain big pictures, simple words, colourful, and they should be readable and interactive for children. It was shown when the teacher phrased about the storybooks during interview session as below:

Cukup sulit mencari buku bergambar yang lucu-lucu dan menarik seperti 'buku buatan luar negeri'. Buku bergambar bahasa Indonesia pun hanya dapat ditemukan di toko-toko buku besar, seperti

Gramedia. Dan 'harganya lumayan juga'. Jadi, di sini saya menggunakan buku-buku yang walaupun kecil tapi menarik.

(Wawancara \#2, 31/5/2016)

(It is quite hard to find funny and interesting picture books like imported books from abroad. We can only find Indonesia picture books in a big bookstore, like Gramedia. And the price also quite expensive. So, here, I use interesting small books.)

(Interview \#2, 31/5/2016)

The next step is about setting the seat arrangement. As suggested by Wright (2009) that the appropriate seat arrangement in storytelling activity is U-shape. In the 1 st meeting, the seat arrangement and the picture book chosen were not set as a must list on the lesson plan. So, when children seemed excited to the story-reading session, it seemed very hectic.

The teacher shows a book, entitled "Lampu KunangKunang". Children seemed so excited. They started to ask questions and giving opinions. The situation comes hectic when some children in the back line complaint to the children on the front line. Also, the other children were seemed like tired and a child is running around the class. And some want to touch the book. Hence, the teacher is distracted and tries to solve the problem (in the middle of the storyreading session) to set the seat arrangement. A $U$ shape position is a teacher's choice. By having this 
children's position, it will help the teacher to interact the picture book to her children.

(Obs \#1, 30/5/2016)

The situation described based on observation data is relevant to Piaget "s theory (1963) who stated that the children are active learners (Pinter, 2006). It was really described when they really wanted to touch and play with the picture book of Lampu Kunang-Kunang shown. It is supported by Machado (1980) who states that interaction, such as seeing, touching, and interacting with the books read is needed to be built in early childhood education quality program to make 'storytime' fun and meaningful. Thus, the activities of telling stories and getting children's attention to join in the storyreading session were also being the teacher's challenges.

At the last session, reviewing the storybook through a few question-answer session (Q\&A) or discussion was chosen.

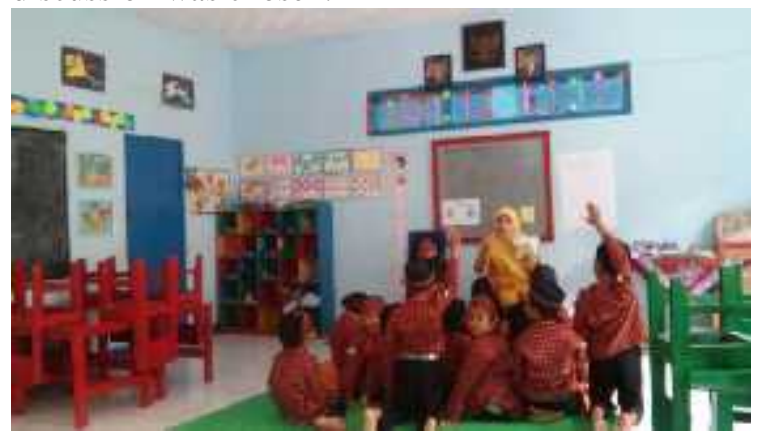

Figure 5. Q\&A Session with Children

Those are relevant to Kim's (1990) statement that all the steps of storytime (before-during-after) can help develop children's cognitive skill in process of intellectual because the use of story in the language classroom gives a lot of learning experiences to children naturally from the linguistics features, vocabularies, and its comprehension as well. The questions, after a story-reading session, can clear up ideas, encourage the use of vocabularies, and pinpoint parts that are especially enjoyed. Here, respondent's excerpt also showed that children like to discuss what story is about, retell the story and/or continue the story using their own words.

Setelah selesai ketiga kegiatan diatas, anak-anak berkumpul kembali di circle time untuk mendengarkan cerita dari buku cerita yang dibacakan. Anak-anak sangat antusias mendengarkan cerita itu dan mampu menjawab pertanyaan tentang inti dari cerita tersebut setelah buku selesai dibaca. Hampir $60 \%$ anak ingin menjawab pertanyaan tentang cerita, tapi berhubung waktu hanya beberapa orang yang berkesempatan memberikan jawaban. (Jurnal Guru \#4, 2/6/2016)

After three activities above has finished, children stay in circle time to listen to the story through the book read. Children seem very enthusiastic in listening to the story and they can answer some questions related to the story. Because of the time limitation, only some children were chosen to have the opportunity to answer whereas almost $60 \%$ of children want to answer questions.

(Teacher's Journal \#4, 2/6/2016)

In the 4th meeting, some children were confused to understand the teacher's question. The teacher repeated the question three times and children still seemed to be confused. Shortly, the teacher skipped the question. Therefore, after classroom activity was over, teacher and researchers had an evaluation for this new challenge. And the result agreed if children still did not get with a simpler one, the questions were changed to gain children's concept of knowledge. Thus, the storyreading activity was memorable and meaningful for children because they could also review the knowledge that is attained during story-reading.

\section{CONCLUSIONS}

This study has portrayed the teacher's challenges faced in story-reading as a teaching method to young children. Based on the findings and discussions shown, story-reading activity raises children's enthusiastic in reading. Not only reading, listening and speaking skills are also stimulated. For instance in reading aloud session, children try to listen to the story and when discussion or question-answer session, children tried to speak up and utterance their knowledge or opinion.

Furthermore, teacher's challenges could be found in every step of story-reading session; before, during, and after story-reading session. Such as the lack of references of good and suitable educated storybooks, either in terms of the plot/content, font size, or the design; and setting arrangement in the classroom during story-reading. Early challenges found were about children attentions and the teacher's high level language offered. Nonetheless, the challenges faced got to be resolved through discussion between teacher and researchers. So, those challenges will never be problem for teacher.

Even this study was only taken for limited meetings and preparation; the researchers did this research maximally through collaborating with kindergarten teachers in Bandung. We all hope this 
study of BKBB teaching model will be gained in bigger limitation.

\section{ACKNOWLEDGEMENTS}

Ibu Tatien, as respondents in this study, for conducting BKBB teaching model corporately in Bandung. We thank to Kementrian Riset Teknologi Dan Pendidikan Tinggi Republik Indonesia (RISTEKDIKTI) and Lembaga Penelitan dan Pengabdian kepada Masyarakat (LPPM) Universitas Pendidikan Indonesia for providing the financialhelp to accommodate teaching model based on Budaya, Karakter Bangsa dan Bermain (BKBB) or Teaching Model based on Learning Culture, National Values, and Playing project in Bandung.

\section{REFERENCES}

Alwasilah, A. Chaedar. (2002). Pokoknya Kualitatif; Dasar-Dasar Merancang dan Melakukan Penelitian Kualitatif. Jakarta: Pustaka Jaya.

Brewster, J \& Ellis, G. (2003). The Primary English Teacher's Guide. England: Penguin English.

Bogdan and Biklen. (1992). Qualitative Research for Education: an Introduction to Theory and Method. Boston: Allyn and Bacon Inc.

Calkins, L. M. (2001). The Art of Teaching Reading. United States: Addison-Wesley Educational Publishers Inc. Cohen, L., Manion, L., \& Morrison, K. (2007). Research methods in education. London and New York: Routledge. Retrieved from http://knowledgeportal.pakteachers.org/sites/kn owledgeportal.pakteachers.org/files/resources/ RESEARCH METHOD COHEN ok.pdf

Essa, E. L. (2003). Introduction Early Childhood Education (4th ed).Clifton Park, NY: Delmar Learning.

Harmer, J. (2003). How to Teach English. Edinburgh: Longman.

Harste, J., Short, K., \& Burke, C. (1988). Creating Classroom for Author: The Reading-Writing Connection. New Hampshire: Heinemann.

Fellowes, J. \& Oakley, G. (2014). Language Literacy and Early Childhod Education. Australia dan Selandia Baru: Oxford University Press.

Kim, Sook-Yi. (1999). The Effect of Storytelling and Pretend Play on Cognitive Processes, Short-Term and Long-Term Narrative Recall. Child Study Journal. 29 (3), 175-185.

Leuenberger, C. J. (2003). The New Kindergarten: Teaching Reading, Writing, and More. New York: Scholastic Professional Books.
Machado, J. M. (1980). Early Childhood Experiences in Language Arts (2nd ed). Clifton Park, NY: Delmar Learning.

Mooney, C. G. (2000) Theories of Childhood. An Introduction to Dewey, Montessory, Erickson, Piaget \& Vygotsky. St Paul: Readleaf Press.

Morrow, L. M. (1996). Literacy and Young Children: Research-based Practices. New York: The Guilford Press.

Piaget, J. (1963). The Language and Taught of Children. London: Routledge and Kegan.

Pinter, A. (2006). Teaching English to Children. London: Oxford University Press.

Richards, K. (2009). Interviews. Qualitative research in applied linguistics. (in J. Heigham \& R. Croker Eds.). Basingstoke: Palgrave Macmillan.

Rog, L. G. (2001). Early Literacy Instruction in Kindergarten. Newark: International Reading Association.

Suyanto, K. (2008). Teaching English to Young Learners. Jakarta: Bumi Aksara.

Wright, A. (2009). Storytelling with Children. London: Oxford University Press. 